\title{
FATE OF CONTAMINANTS OF EMERGING CONCERN IN A SINKHOLE LAKE, FLORIDA, USA
}

\author{
USODA SKRB VZBUJAJOČIH ONESNAŽEVAL V JEZERIH, \\ NASTALIH V VRTAČAH, FLORIDA, ZDA
}

\author{
Ethan UPTON ${ }^{1}$, Philip VAN BEYNEN ${ }^{2,}$, \\ Ela BIALKOWSKA-JELINSKA ${ }^{2} \&$ Laurent CALCUL ${ }^{3}$
}

\begin{abstract}
UDC 504.5:556.33:551.448(735.9)

556.33:628.42(735.9)

Ethan Upton, Philip van Beynen, Ela Bialkowska-Jelinska \& Laurent Calcul: Fate of Contaminants of Emerging Concern in a Sinkhole Lake, Florida, USA

Highly karstified carbonate platforms such as Florida are characterized by rapid infiltration rates, highly permeable bedrock and the direct connection to the below aquifer through the high density of sinkholes. This combination of physical features makes the groundwater and aquifers highly vulnerable to contamination from synthetic chemicals commonly referred to as contaminants of emerging concern (CECs). The use of septic tanks, otherwise referred to as onsite water treatment systems (OWTS), promotes the introduction of CECs into the environment. In order to study the impacts of CECs from OWTS on a karst landscape, water, sediment, and vegetation samples were collected in a sinkhole lake surrounded by residential housing using this waste disposal method. The main question of this research project is what is the fate of CECs from OWTSs effluent within the catchment of a sinkhole lake? Liquid chromatograph mass spectrometry was used to analyze the samples for the presence of CECs. It was found that the relative quantity of CECs in the individual constituents is dependent upon 1) the hydrophobicity and polarity of the individual compound, 2 ) the specific sampling site, 3) the topography gradient, and 4) for vegetation, the connectedness of the sample type to the sediment. Hydrogeological studies have found that the sinkholes of the area are all connected to the below aquifer. Consequently, these CECs pose a risk of the contamination of the
\end{abstract}

Izvleček

UDK 504.5:556.33:551.448(735.9)

\section{Ethan Upton, Philip van Beynen, Ela Bialkowska-Jelinska \& Laurent Calcul: Usoda skrb vzbujajočih onesnaževal v jezerih, nastalih v vrtačah, Florida, ZDA}

Zakrasele karbonatne platforme, kot je Florida, zaznamujejo hitra stopnja infiltracije, visoka prepustnost podlage in neposredna povezava $\mathrm{z}$ vodonosniki prek številnih vrtač. Kombinacija teh fizikalnih lastnosti prispeva $\mathrm{k}$ visoki občutljivosti podtalnice in vodonosnikov na kontaminacijo s skrb vzbujajočimi sintetičnimi kemikalijami. Uporaba greznic spodbuja vnos teh onesnaževal v okolje. Da bi proučili vpliv kemikalij na kraško pokrajino, so bili vzorci vode, sedimenta in vegetacije odvzeti $\mathrm{v}$ jezeru, nastalem v vrtači in obdanem s stanovanji, ki so opremljena $\mathrm{z}$ greznicami. Glavno vprašanje tega raziskovalnega projekta je, kaj se dogaja $\mathrm{z}$ onesnaževali iz grezničnih odplak $\mathrm{v}$ vodnem zajetju vrtače. Za analizo vzorcev je bila izvedena masna spektrometrija s tekočinsko kromatografijo. Ugotovljeno je bilo, da je sorazmerna količina kemikalij odvisna od 1) hidrofobnosti in polarnosti spojine, 2) mesta vzorčenja, 3) topografskega gradienta in 4) za vegetacijo, povezanosti vrste vzorca s sedimentom. Hidrogeološke študije so pokazale, da so vrtače na tem območju povezane $\mathrm{z}$ vodonosnikom, ki je pod njimi. Posledično skrb vzbujajoča onesnaževala predstavljajo tveganje za onesnaženje podtalnice. Ta študija je prikaz razmer $\mathrm{v}$ sušni sezoni Floride, to je najverjetneje obdobje z najmanjšo kontaminacijo. Vzorčenje bi bilo treba opraviti v tudi deževnem obdobju, ko izpiranje onesnaževal iz greznic lahko poveča koncentracije onesnaževal, tako $\mathrm{v}$ jezeru kot $\mathrm{v}$ vodonosnikih, kar je

${ }^{1}$ Geosyntec,12802 Tampa Oaks Blvd., Suite 151, Tampa, FL, 33637, USA; e-mail: EUpton@Geosyntec.com

${ }^{2}$ School of Geosciences, University of South Florida, 4202 E. Fowler Ave, Tampa, FL 33620, USA; e-mails: vanbeyne@usf.edu, elzbieta@mail.usf.edu

${ }^{3}$ Department of Chemistry, University of South Florida, 4202 E. Fowler Ave, Tampa, FL 33620, USA; e-mail: calcul@usf.edu

* Corresponding author 
groundwater. This study is a temporal snapshot, that being the dry season of Florida which is most likely the time of lowest CEC contamination. It is imperative that sampling extend into the wet season when flushing of CECs from the OWTS may increase their concentrations in both the lake but also the aquifers especially since residents use well water as their source of potable water. While this study is based in Florida, we strongly suspect that our findings and recommendations are applicable more generally as OWTS are used throughout the many karst regions of the world.

Key words: sinkhole lake, contaminants of emerging concern, Florida, karst, onsite water treatment systems. posebno problematično zaradi uporabnosti vode iz vodnjaka $\mathrm{v}$ prehranske namene. Čeprav je bila študija izvedena na Floridi, verjamemo, da so naše ugotovitve in priporočila splošno uporabni, saj se greznice uporabljajo v številnih kraških predelih sveta.

Ključne besede: jezero v vrtači, skrb vzbujajoča onesnaževala, Florida, kras, greznice.

\section{INTRODUCTION}

The overlap of anthropogenic activity and groundwater usage greatly increases the risk of contamination of water supplies, especially from chemicals which are used every day to promote human health and well-being. These include drugs such as anti-inflammatories, beta-blockers, anti-depressants, and hormones; along with sunscreen, insect repellents, and fragrances. Such synthetic chemicals, when introduced into the environment, are often termed Contaminants of Emerging Concern (CECs). The anthropogenic introduction of CECs into the aquatic environment, often via onsite water treatment systems (OWTSs), more commonly known as septic tanks, has adverse effects on human water supplies and biota in the environment (Ricart et al. 2010; Brausch \& Rand 2011; Li et al. 2016; Zhang et al. 2019). Their presence, transport, and persistence can be influenced not only by how they are released but also by geology and climate.

Highly porous carbonate landforms such as karst have very high infiltration rates and facilitate the rapid transport of CECs (Gutiérrez et al. 2014; Seal et al. 2016; Dodgen et al. 2017). Sinkholes can form in areas where dissolution of the underlying calcite bedrock (karstification) has occurred due to undersaturated, acidic water infiltrating, creating voids for which overlying sediment or bedrock can enter (Kaufmann \& Dreybrodt 2007; Gutiérrez et al. 2014). With little CEC removal due to the rapid infiltration and high permeability of the karstified carbonate platform and the direct connection of sinkholes to the below groundwater, karst aquifers are highly vulnerable to contamination from OWTSs and surface runoff (Gutiérrez et al. 2014; Dodgen et al. 2017). The anthropogenic introduction of CECs into aquifers, waterways, and inland water bodies, has adverse effects on the environment and on human health at varying degrees depending on the individual contaminant, concentration, and additive effects of the combination of multiple chemicals.

A handful of studies have investigated CECs in karst environments. Katz and Griffin (2008) detected CECs in springs and groundwater wells in the upper Floridan Aquifer. They suggested that upgradient sinkholes may have been the input source of this pollution. Dodgen et al. (2017) studied the presence of CECs and other pollutants in a karst aquifer of southwestern Illinois, USA. This study used a broad scale sampling regime of springs in the region. They found that all the springs were contaminated with CECs. While the authors collected samples throughout the year, they did not see any seasonal trends in the data. In a study conducted in Barbados, Edwards et al. (2017) investigated CECs released from municipal water treatment plants and found that the nature of the karst setting increased the threat posed by CECs to the marine environment when they were discharged into the coastal zone.

The aim of this research is to determine the presence and fate of CECs within the water, sediment, and vegetation of a sinkhole lake that receives runoff from residences using OWTSs. This site is representative of many locations in Florida where sinkholes are very common and often surrounded by lower density, older residential areas that are reliant on OWTS as the only means of human waste disposal. Consequently, it is imperative that we understand the partitioning of the CECs in physical environment to determine the potential adverse effects on water supplies but also biota that live in these water bodies. While this study is a temporal snapshot, it represents a time before potential flushing of CECs into the sinkhole lake that coincides with the onset of the wet season. Consequently, it provides important information on base-level conditions for future studies investigating the impact of the seasonal increase in precipitation. However, with Florida predicted to experience greater variability in precipitation (flooding/droughts), climate conditions such as the one we are investigating (less precipitation) may become more prevalent. 


\section{STUDY AREA}

Florida is a carbonate platform consisting of Swannee and Ocala limestone formations. These host the Surfical, Intermediate, and Floridan aquifers which are significant sources of potable water for the region. Of the three main aquifers in Florida, the first two are of particular interest to our study. The Surficial Aquifer is unconfined and can be found within unconsolidated sand, shelly sand, and shell while the Intermediate Aquifer is confined and is comprised of permeable layers of sand, shell and limestone separated by clay confining units (Florida Department of Environmental Protection 2015). The limestone of Florida has been intensively karstified with many sinkholes providing hydrologic access to the aquifers (Tihansky 1999). Due to rapid population growth and the agricultural and urban development, much of Florida's nat- ural environment is highly impacted by anthropogenic activity. OWTS are common in rural, exurb, and some older suburban neighborhoods. Much of the effluent from these OWTS can leach into the karst sinkhole lakes and/or the groundwater.

This study was conducted in the Riverview township of Hillsborough County Florida in the Bell Creek Watershed. The Bell Creek watershed is a sub-watershed of the Alafia River located in Hillsborough County, Florida (Haber \& Mayfield 2003). The landuse is low density residential with single family homes. The sinkhole lake study area is located west-northwest of Lake Grady (Fig. 1) and is surrounded by residential homes built in the 1970s each using OWTS as their means of waste treatment. It is also important to mention that groundwater via wells

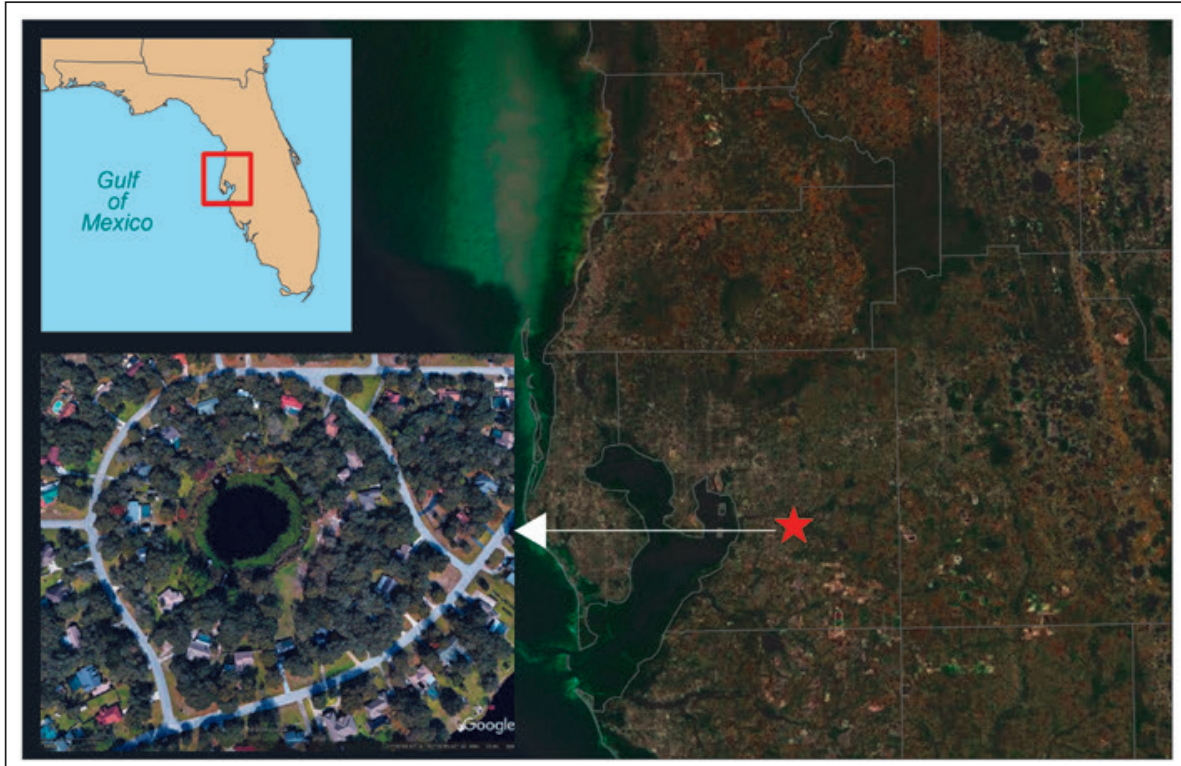

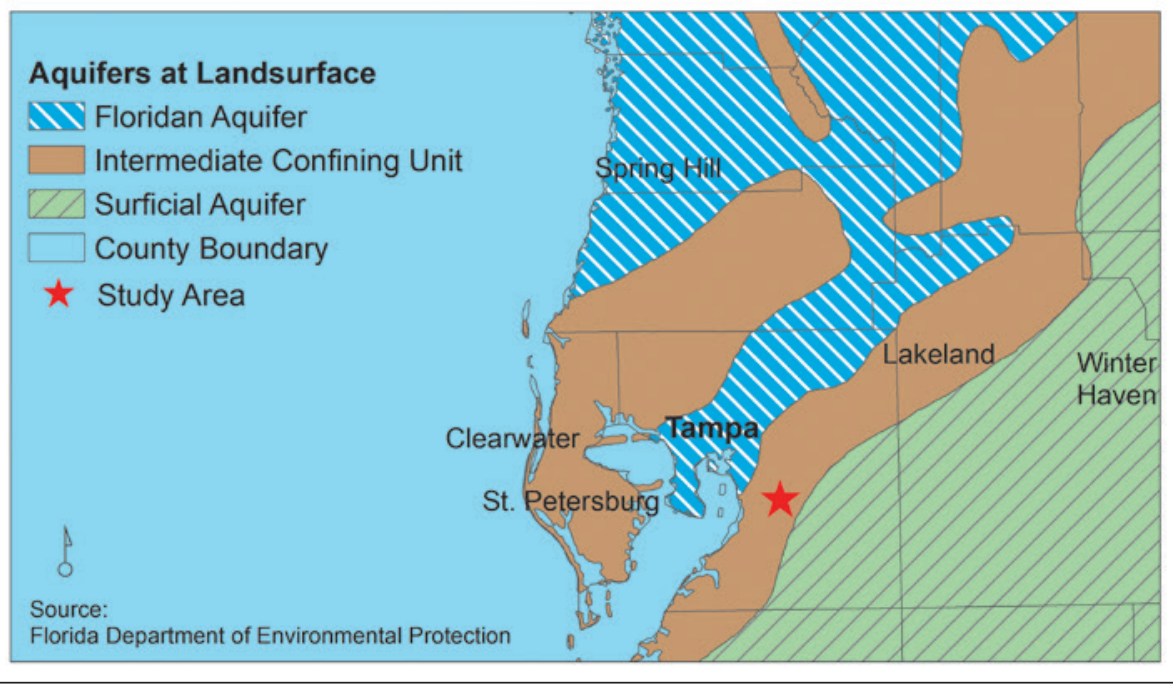

Fig. 1: Study area is within the city limits of Riverview in Tampa Bay, Florida. The study area lies above the Intermediate Aquifer System (Google Maps 2019). 
is the only source of potable water for the neighborhood surrounding the lake. Wells in the area are commonly at depths of approximately $75 \mathrm{~m}$ which would tap into the Upper Floridan Aquifer (Haber \& Mayfield 2003), the most utilized karst aquifer in the state of Florida.

The sinkhole lake has a ribbon of riparian vegetation consisting of cattails, water lilies, and duckweed. The distance from the homes to the riparian zone is $\sim 30-40$ meters. The western side of the lake has a greater elevation incline compared to the eastern side of the lake. For the period from 1981 through 2010 the precipitation average for the dry season ( 7 months from November to May) is $348 \mathrm{~mm}$ while the wet season (5 months from June to October) averages $764 \mathrm{~mm}$. The mean average temperature for Riverview is $22.2^{\circ} \mathrm{C}$.

\section{METHODS}

In the February 2019, water, sediment, and the most abundant species of aquatic vegetation (water lilies representing the emergent plants and duckweed the floating plants) were collected from two sites at opposite sides of the lake. The lake water (LW) samples were collected first so that the removal of the sediments and vegetation would not introduce sediments not normally suspended in the water column. The samples were collected midway down the water column approximately $350 \mathrm{~mm}$ from the surface. Bottles were filled to the top in order to minimize the contact between water and air and placed in a cooler filled with ice. Sediment grab samples were collected using a stainless steel scoop and deposited into $500 \mathrm{~mL}$ amber glass jars. The water lily (WL - Nymphaea aquatic) was collected in its entirety including the roots, stem and leaf and placed in $500 \mathrm{~mL}$ amber glass jars. The entire duckweed plant (DW - Spirodela polyrhiza) was deposited into a $500 \mathrm{~mL}$ amber glass jar. The samples were transported to the Chemical Purification Analysis and Screening core facility (CPAS) at the University of South Florida (USF) in Tampa, Florida. The water samples were stored at $4{ }^{\circ} \mathrm{C}$, and sediment and plant samples at $-20{ }^{\circ} \mathrm{C}$ until sample preparation. The sample preparation and analytical methods were based on the procedures of Anumol et al. (2013), Fairbairn et al. (2015) and Petrie et al. (2017).

Lake water samples were filtered twice through a vacuum assisted Whatman $0.7 \mu \mathrm{m}$ glass microfiber fiber (GF/F) filter. The sediment samples were thawed to room temperature and sieved through $2 \mathrm{~mm}$ sieve. The plant samples were cleaned for 2 min under deionized water and cut into small pieces. All prepared samples were frozen and lyophilized. Extraction was performed by using Anton-Paar Monowave 300 Reactor. $0.5 \mathrm{~g}$ of a target sample (either the biota, sediment, or water samples) was mixed with $25 \mathrm{~mL}$ of $25: 75 \mathrm{MeOH}: \mathrm{H}_{2} \mathrm{O}(\mathrm{v} / \mathrm{v})$ in a $30 \mathrm{~mL}$ vessel. Samples were heated to $50{ }^{\circ} \mathrm{C}$ over 10 minutes and maintained at this temperature for 30 minutes. Once cooled samples were filtered through glass microfiber fi- ber filter $(0.7 \mu \mathrm{m})$ and diluted with $\mathrm{H}_{2} \mathrm{O}$ to achieve a final $\mathrm{MeOH}$ concentration of $<5 \%$.

$500 \mathrm{mg}$ Oasis hydrophilic-lipophilic balance (HLB) cartridges were preconditioned with $2 \mathrm{~mL} \mathrm{MeOH}$ followed by $2 \mathrm{~mL} \mathrm{H}_{2} \mathrm{O}$ at a flow rate of $1 \mathrm{~mL}$ per min. Samples were then deposited into the cartridges at the same flow rate and dried under vacuum. Analytes were then eluted using $8 \mathrm{~mL} \mathrm{MeOH}$ at a flow rate of $1 \mathrm{~mL}$ per minute and then dried under a continuous flow of nitrogen. Dried extracts were reconstituted in $0.5 \mathrm{~mL} \mathrm{80:20}$ $\mathrm{H}_{2} \mathrm{O}: \mathrm{MeOH}(\mathrm{v} / \mathrm{v})$, and filtered through $0.45 \mu \mathrm{m}$ polyvinylidene fluoride (PVDF) filters and transferred to vials.

The liquid chromatography mass spectrometry (LCMS) analysis was carried out using an Agilent 1260 infinity high-performance liquid chromatography (HPLC) coupled to a 6460 triple quadrupole $(\mathrm{QqQ})$ mass spectrometer with the Agilent jet stream electrospray ionization (ESI) source. The presence of particular CECs was determined by tandem mass spectrometry (MS/MS) and multiple reaction monitoring (MRM). To ensure maximum sensitivity for the varied range of studied CECs, the data acquisition was performed in positive and negative ESI modes. The mobile phase for positive mode used two solvents: (A) Milli-Q water with $0.1 \%(\mathrm{v} / \mathrm{v})$ formic acid and (B) acetonitrile with $0.1 \%(\mathrm{v} / \mathrm{v})$ formic acid. With a constant flow rate of $1 \mathrm{ml}$ per min, initial conditions of $100 \%$ solvent A were maintained for 2 min before reducing to $0 \%$ within $23 \mathrm{~min}\left(25^{\text {th }} \mathrm{min}\right)$ and returned to starting conditions after $4 \mathrm{~min}\left(29^{\text {th }} \mathrm{min}\right)$. A post-run of 2 min was added to allow the column to re-equilibrate before the next analysis. The mobile phase for negative mode used: (A) Milli-Q water with $1 \mathrm{mM}$ ammonium fluoride and (B) $65 \%$ methanol and $35 \%$ acetonitrile. With a constant flowrate of $0.9 \mathrm{ml}$ per min, initial conditions of $95 \%$ solvent A were maintained for $2 \mathrm{~min}$ and reduced to $5 \%$ at $25^{\text {th }}$ min, and increased to $95 \%$ at $29^{\text {th }}$ min. A post-run time of 5 min was necessary. Both methods utilized a Phenomenex Synergi Fusion-RP C18 HPLC column ( $250 \times 4.6 \mathrm{~mm}, 4 \mu \mathrm{m}$ particle size $)$. The 
column was maintained $25^{\circ} \mathrm{C}$ and the injection volume for both modes was $20 \mu \mathrm{L}$.

Comparing the retention time of the samples with internal standards available in our laboratory, as well as using MRM method allowed the presence of the CECs in the analyzed samples to be determined. At the time of analysis, 12 standards of common CECs were available and run through LC-MS. These included atenolol, caffeine, $N, N$-diethyl-m-toluamide (DEET), theophylline, triclosan, acetaminophen, metoprolol, propranolol, sulfamethoxazole, diclofenac, ibuprofen, and naproxen.

\section{RESULTS}

Qualitative analysis of 34 CECs was conducted to determine their partitioning within the lake water, sediments and vegetation. A comparison of the peak height and retention times (sample peaks that fell within 0.1 minutes of the standard) of the collected lake samples and these standards revealed five corresponding compounds: atenolol, caffeine, DEET, theophylline, and triclosan (Tab. 1). These findings were confirmed using the MRM method (Fig. 2).

The pharmaceutical Atenolol had the greatest relative quantity of all the sample types is found in the vegetation, followed by the water, and lastly the sediment. The highest average quantity of atenolol were in the WL and DW respectively at sampling site 2 (SS2). Caffeine, a widely used stimulant had greatest quantities in the water relative to the vegetation and sediment. The insect repellent DEET was found in all samples and in the greatest quantity of all five CECs. SS1 has more of this compound than the samples at SS2. Of the samples analyzed, the WL at SS1 has the greatest quantity of DEET followed by the sediment at SS1 with both having significantly higher relative levels than SS2. DEET was present in a well water sample at SS1. Theophylline, a pharmaceutical, had average relative quantities from greatest to least are: $\mathrm{WL}$, DW, LW, and sediment. In the natural environment and the human body, theophylline is present as a degradation product of caffeine (Tang-Liu et al. 1983). The vegetation and the water contain the highest levels of theophylline due to its hydrophilic nature. An observation worth noting is that SS2 has more of the compound relative to SS1. However, like the caffeine samples, the SS1 LW sample contains the greatest quantity of theophylline overall. With the exception of the lake water at SS1, the next four highest quantities consist of all vegetation which is to be expected from the high hydrophilicity of theophylline. An ingredient in personal care drugs, Triclosan's greatest quantities are found in the LW followed by the sediment. The relative quantities from largest to smallest are as follows: the LW sample at SS1, the sediment sample at SS2, the LW sample at SS2, and the sediment sample at SS1.

Other possible CECs found using MRM method using the electrospray ionization positive mode included sucralose, TCEP, TCPP, fluoxetine, testosterone, androstenedione, carbamazepine and cotinine. Other potential CECs found in the electrospray ionization negative mode are $17 \alpha$-ethynyloestradiol, $17 \beta$-estradiol, estrone, gemfibrozil, and bisphenol-A. Their presence is highly likely but the internal standards that were needed to support these findings were not available at the time of analysis.

\section{DISCUSSION}

\section{PRESENCE OF CECS IN THE LAKE}

The CECs found in this study all fall in the category of pharmaceuticals and personal care products (PPCPs) which can only be sourced to the residents' OWTS. Our results are congruent with similar studies conducted by Bloomfield et al. (2006), Godfrey et al. (2007), Carrara et al. (2008), Del Rosario et al. (2014) and Prosser and Sibley (2015). The uptake of contaminants from vegetation is consistent with Schnoor et al. (1995) in which Lemna minor or duckweed is a hyperaccumulator and helps to mitigate the contamination of aquatic environments.

Atenolol is a synthetic compound used in products to treat high blood pressure and to reduce the risk of heart attacks. The results of this study and of other OWTS effluent studies show that Atenolol can persist through the OWTS filtration process and the compound therefore enters the downstream environment (Subedi et al. 2015). Atenolol's $\log \mathrm{k}_{\mathrm{ow}}$ value is 0.16 showing its hy- 


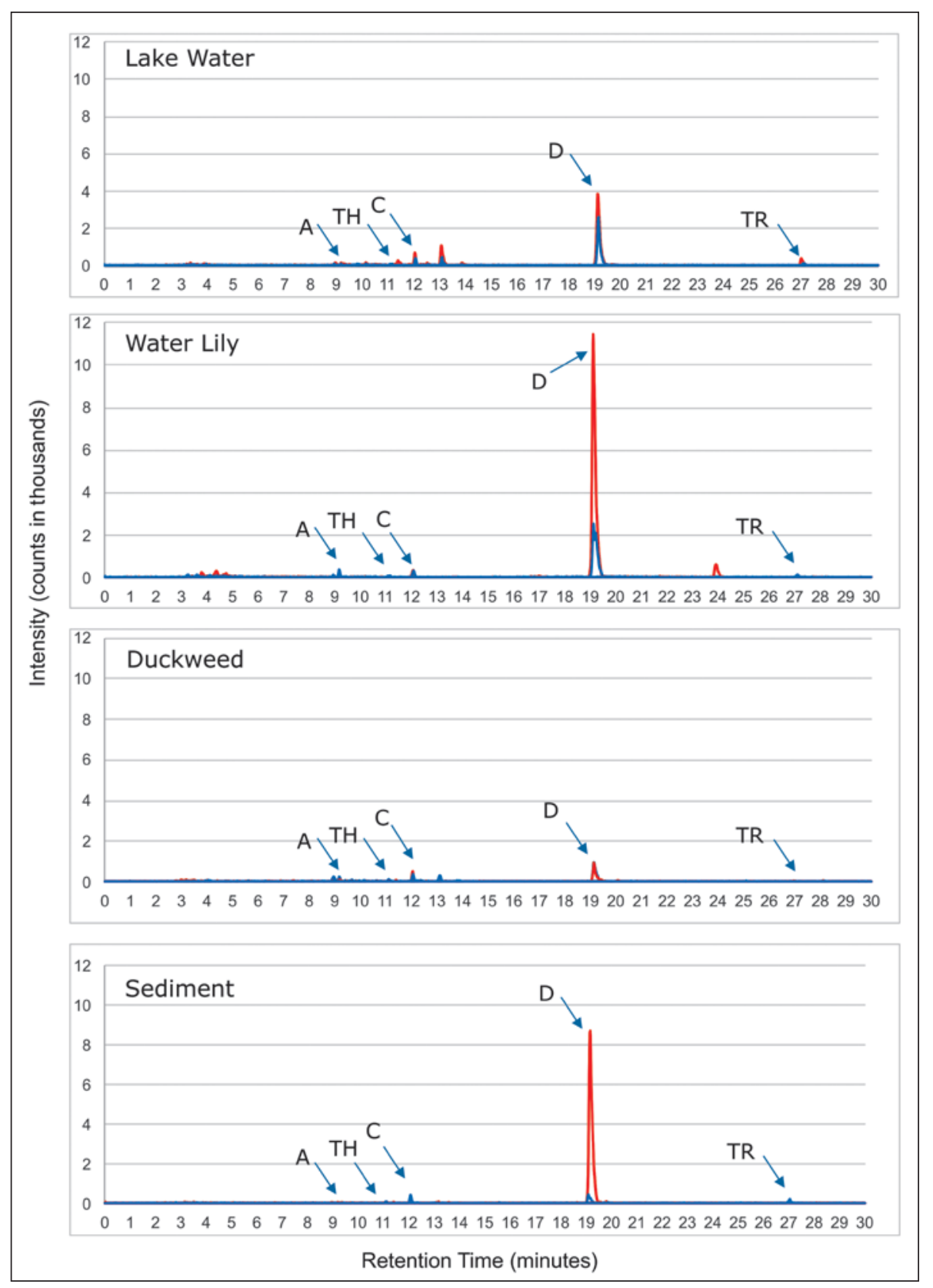

Fig. 2: Superimposed MRM chromatograms of the most abundant product ions of the CECs identified in the samples: atenolol (A), caffeine (C), DEET (D), theophylline (TH), and triclosan (TR). SS1-red and SS2 - blue.

drophilic tendencies. This property allows the compound to transpire into the tissue of the aquatic vegetation and may bioaccumulate (Goswami et al. 2018). This could provide an explanation for why the vegetation samples contain the highest quantity of the compound. Because atenolol is transported by the OWTS's effluent and is hydrophilic, the LW samples have higher concentrations than the sediment.

The soluble stimulant caffeine, used in food and drink products, is commonly found in OWTS effluent (Conn et al. 2010; Katz et al. 2010; Del Rosario et al. 2014). Due to its high solubility and hydrophilicity (log $\mathrm{k}_{\mathrm{ow}}$ value is -0.07), the greatest quantities are seen in the water relative to the vegetation and sediment. Vegetation contains the second highest quantity once again due to caffeine's soluble nature. An explanation for the higher levels at SS1 may be greater consumption from those home owners who live on that side of the sinkhole lake and as a result produce greater output from the OWTSs near SS1. Another possible explanation is the steeper hydraulic gradient at SS1 than at SS2 (see section Influence of the Hydraulic Gradient). The increased gradient creates a greater hydraulic head of the water table thereby increasing the flow of contaminated water from the 
Tab. 1: Results for the most intense MRM transitions from precursor to product ions of the identified CECs.

\begin{tabular}{|c|c|c|c|c|c|}
\hline Tested CEC & $\begin{array}{c}\text { Fragmentor } \\
\text { voltage }\end{array}$ & $\begin{array}{c}\text { Collision } \\
\text { energy (v) }\end{array}$ & RT (min) & $\begin{array}{c}\text { MRM transitions } \\
\text { (m/z) }\end{array}$ & IS confirmation \\
\hline Androstenedione & 107 & 20 & 19.9 & $287>109$ & No \\
\hline Atenolol & 134 & 21 & 9.1 & $267>190$ & Yes \\
\hline Bisphenol A & 120 & 10 & 22.8 & $227>212$ & No \\
\hline Caffeine & 110 & 25 & 12.1 & $195>138$ & Yes \\
\hline Carbamazepine & 110 & 15 & 10.3 & $237>179$ & No \\
\hline Cotinine & 90 & 25 & 8.9 & $177>80$ & No \\
\hline DEET & 110 & 30 & 19.1 & $192>119$ & Yes \\
\hline Estrone & 136 & 40 & 24.6 & $269>145$ & No \\
\hline 17 -estradiol & 171 & 40 & 20.6 & $271>183$ & No \\
\hline $17 \alpha-$ ethynyloestradiol & 139 & 36 & 24.1 & $295>145$ & No \\
\hline Fluoxetine & 90 & 5 & 19.7 & $310>148$ & No \\
\hline Gemfibrozil & 100 & 5 & 23.9 & $249>121$ & No \\
\hline Sucralose & 110 & 15 & 24.6 & $419>239$ & No \\
\hline TCEP & 95 & 10 & 18.6 & $285>222$ & No \\
\hline TCPP & 72 & 16 & 21.1 & $327>99$ & No \\
\hline Testosterone & 116 & 20 & 19.8 & $289>109$ & No \\
\hline Theophylline & 90 & 15 & 11.4 & $181>124$ & Yes \\
\hline Triclosan & 75 & 5 & 26.9 & $287>35$ & Yes \\
\hline
\end{tabular}

OWTs into the lake. The hydraulic gradient (see section Influence of the Hydraulic Gradient) and percolation rate through soil media (see section CECs in Groundwater) greatly impact pollutant transport (Phillips 1989; Deng et al. 2009; Zhang et al. 2013; Shrestha et al. 2016). Seeing as SS1 is relatively closer to the sinkhole lake waterline and has a steeper slope, the CECs would have less time to degrade and would enter into the lake environment in greater quantities. This would result in greater relative quantity of caffeine at SS1 than at SS2. Furthermore, the DW that lives on top of the water contains the second highest caffeine relative quantity due to its direct connectedness to the water and its separation from the inorganics of the sediment. That being said, the WL also contains the presence of caffeine but slightly less relative to DW drawing the conclusion that the polarity and solubility of caffeine is easily absorbed by organics.

DEET is a compound commonly found in wastewater effluent (Singh et al. 2010; Weeks et al. 2012; Del Rosario et al. 2014) so it is not surprising that it is present in our water samples. DEET, being non-polar and lipophilic with a $\log \mathrm{k}_{\mathrm{ow}}$ of 2.97 would not be expected to be present in the organic constituents but is found in the WL. The reason for the large quantities at SS1 and small quantities at SS2 can be explained by the 1) input of DEET from OWTSs and preferential flow from OWTSs near and around SS1,2) uptake of DEET by vegetation directly connected to the soil, and 3) organics in the sediment.
Inputs from houses in closer proximity to SS1 may play a significant factor in the difference between the relative quantities of DEET at SS2. Humans near SS1 may be expelling more of the compound through their waste after which it then flows into the sinkhole lake. Like caffeine, the steeper hydraulic gradient at SS1 than at SS2 may also contribute to a reduction of sediment remediation resulting in a greater quantity of DEET at SS1 than at SS2. As the WL has roots in the soil it is most likely that the nonpolar DEET would be found in the inorganic sediment but not absorbed by the WL due to its $\log \mathrm{k}_{\mathrm{ow}}$ of 2.97 . This is however contrary to the results in which the WL at SS1 has the greatest relative quantity of DEET. Upon collecting the sediment samples at the sample locations the top $4 \mathrm{~cm}$ of sediment at SS1 was rich in organic matter and only the top $1 \mathrm{~cm}$ of sediment for SS2. Thus, it is likely that the structure of DEET promotes its adsorbing to the WL root and other organics in the soils and then being absorbed by the plant (Wu et al. 2013). It is more likely that the inputs and topography at SS1 are directly impacting the initial quantity and causing adsorbance to the sediment. DEET was the one CEC that we found in a well water sample at SS1. The importance of this finding is that it demonstrates the direct connection of the OWTS and the groundwater or via the sinkhole lake and the groundwater tapped by the well. However, more research is needed therefore we will not elaborate on this finding any further. 
Theophylline is a polar compound most commonly used in bronchodilator products to treat asthma and is structurally similar to caffeine with one less methyl group. The $\log \mathrm{k}_{\mathrm{ow}}$ of theophylline is -0.89 suggests a high potential of biodegradation. As caffeine can degrade to theophylline naturally in the body and the environment, one would expect there to be a higher proportion of caffeine in the environment than theophylline, as shown in our data. With the exception to the water from SS1, the next four highest quantities consist of all of the vegetation which is to be expected with the high hydrophilicity of theophylline.

The common occurrence of triclosan in anthropogenic hygienic products makes it an excellent tracer for OWTS effluent as seen in a number of studies (Conn et al. 2010; Singh et al. 2010; Svenningsen et al. 2011). Due to triclosan's non-polar, lipophilic ( $\log \mathrm{k}_{\mathrm{ow}}$ value of 4.76) nature, one would not expect to see its presence in the LW which runs contrary to our results. However, due to the percolation and overland flow waters being the main source of transport for this chemical, we would expect it to be highest in the LW until it binds itself to other non-polar, lipophilic compounds. As mentioned previously, the sediment at SS1 is high in organic matter relative to the sediment at SS2 which from observation has a higher sand fraction. The polarity of organic matter may discourage any interaction of triclosan with organics which explains the reduced levels in the vegetation and subsequently with the organic-rich sediment at SS1. The inorganic sediment at SS2 is preferential for the nonpolar triclosan resulting in the binding of the compound to the sediment resulting in the large quantity found in the sample. In addition, the anthropogenic use of triclosan at SS2 may be higher than at SS1 providing greater quantity in the sediment. Not only would greater relative quantities of triclosan at SS2 provide larger quantities overall but would be exceptionally prolific in the inorganic sediment at SS2 as seen in the results. The current levels of the antimicrobial triclosan seen in many areas in the United States are toxic to aquatic bacteria and should be evaluated in the sinkhole lake environment (Ricart et al. 2010).

As CECs degrade, they change their molecular structure. The impact of the degraded compounds could also impact the environment adversely. An example is that of caffeine and theophylline in which theophylline contains one less methyl group than caffeine and can result in further contamination of sinkhole environments. Research into the impacts of the degraded compound structure should be considered based on the precursor compounds' willingness to breakdown into the new compound and the product compounds potential to harm the environment and humans.

\section{INFLUENCE OF THE HYDRAULIC GRADIENT}

Fig. 3 shows the cross-section of the study area showing the surface topography of the sinkhole lake watershed. The topography and house locations were measured using elevation from Google Earth Pro which matched a lower resolution contour map from the USGS. Without the property building permits we made certain assumptions about the placement of the OWTS. The first assumption is that the septic tanks and associated drainfields are close to the house. The second is due to the steep slope

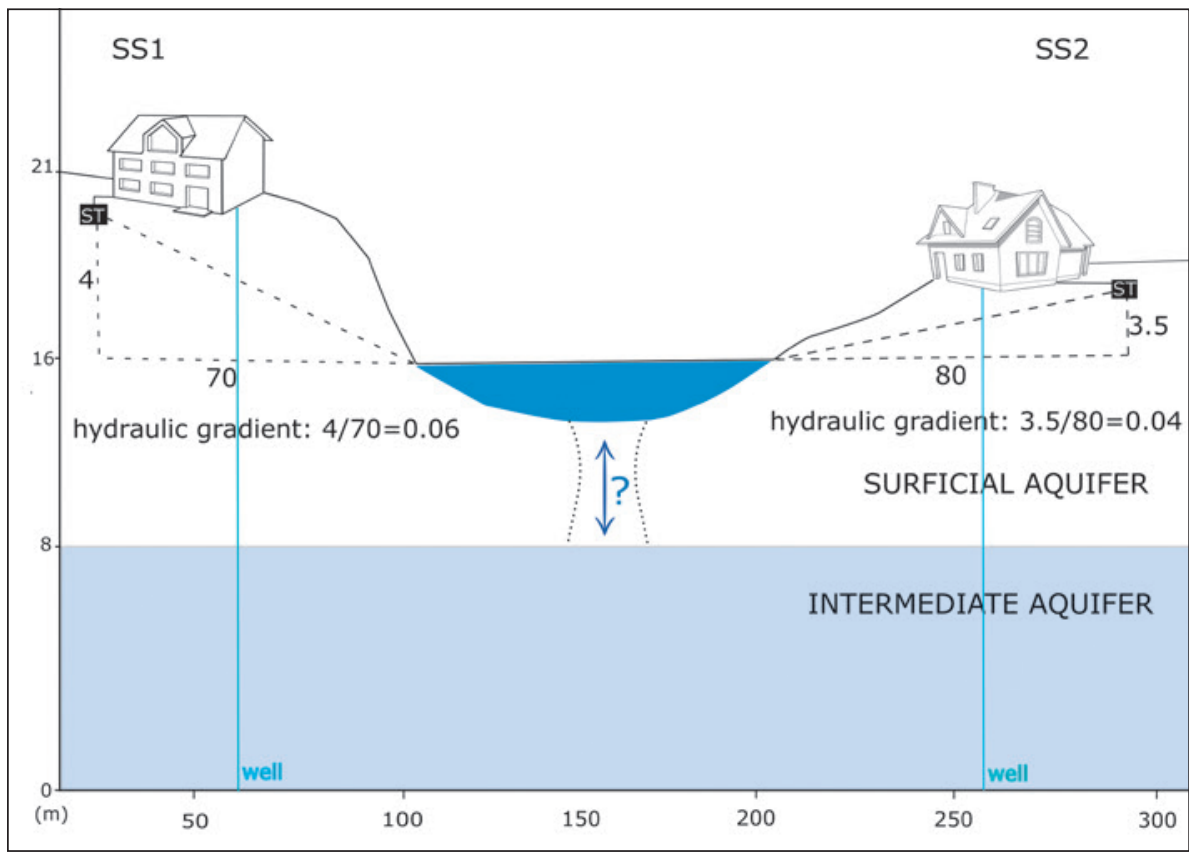

Fig. 3: Cross-section of study area. Note the $y$-axis shows elevations mentioned in text, not exact increments. Houses depicted are not actual representations of the two sites. Septic tanks are abbreviated to ST in the figure. 
of each site, the $30 \mathrm{~m}$ of leachate trenches, characteristic length of OWTS (State of Florida Department of Health 2018), were dug perpendicular to the dip of the slope. Third, with Florida's septic tank regulations for OWTS prohibiting their placement within $15 \mathrm{~m}$ of water bodies, we did not place the drainfield within this distance of the sinkhole lake. The hydraulic gradient (change in depth/ change in length) is greater for SS1 (0.06) compared to SS2 (0.04). Consequently, this provides support for our supposition that a steeper hydraulic gradient may help explain why CECs levels are higher at SS1 compared to SS2.

\section{CECS IN GROUNDWATER}

In late 1999, two sinkholes formed in Lake Grady, an artificial lake created by the damming of a small creek (Haber \& Mayfield 2003). This lake is $300 \mathrm{~m}$ due east of our sinkhole lake. Their study found that sinkhole lakes in the area are connected to the Intermediate and Upper Floridan Aquifers, and consequently, contaminants entering the sinkholes have a high probability of polluting drinking water. Wells from homes to the east of the Lake Grady were found to have elevated levels of E. coli thereby showing contamination of the Upper Florida Aquifer (UFA) from which the wells pulled their water. At the time of the formation of the sinkholes, CECs were not tested. Other wells were also measured for contamination, one of which is located in the general area of our sinkhole lake, but no information was given of its exact location. This well did not show any contamination. Dye tracing done at the time shows that the groundwater was flowing to the east of the Lake Grady (Haber \& Mayfield 2003).

As mentioned above, the all homes in our study area use wells for their potable water. Although we do not know the exact depth of the wells, most in the area are drilled to depths of $\sim 75 \mathrm{~m}$ with casing depth of approximately $20 \mathrm{~m}$ (Cardinale 2000). The casings depth would prevent any leachate from the OWTS drainfields directly entering the well water. However, we strongly suspect that the CECs do enter the Intermediate Aquifer (IA), denoted by question mark in Fig. 3, a supposition based on three factors: 1) The sinkhole lake occupies $7 \%$ of its watershed and with the region's precipitation-evapotranspiration (P-ET) value being $425 \mathrm{~mm}$ (Dohrenwend 1977), it is unlikely that the surface input can sustain the lake during the 8 month dry season; 2) Our sampling occurred mid-dry season and yet the lake level did not appear to have dropped significantly from the wet season. We base this conclusion on the fact that the lake entirely flooded the riparian zone. If the water level drops during the dry season, then the edge of the riparian vegetation contain no water; and 3) the area's potentiometric surface of the IA is less than $8 \mathrm{~m}$ below the surface of the lake (Haber \& Mayfield 2003). Consequently, to sustain the lake during the entire dry season, there must be a connection of the base of the lake with the below aquifer and therefore contaminants could enter the aquifer.

The importance of the Surficial Aquifer should not be understated for our study site as the CECs from the OWTS will pass through this aquifer before entering the lake. However, if the soil becomes saturated during the wet season, the CECs normally contained in the OWTS drainfield may instead be flushed from the soil into the lake during heavy downpours from intense thunderstorms or tropical storms.

\section{CECS IMPACT OF LAKE FLORA AND FAUNA}

Bioaccumulation of CECs is a distinct possibility based on the results of this study. The vegetation has shown to uptake CECs in different quantities based on the physiochemical structures of the individual compounds and of the biological properties of the vegetation. DEET and Triclosan have the chemical structure to resist degradation but may or may not degrade depending on the vegetation and physiochemical properties of the sinkhole lake water and the surrounding environment. Additionally, contaminants may be problematic for the aquatic animal species which feed on plants and organisms within the lake. Conversely, one could draw the conclusion that vegetation is beneficial for remediating CECs in the environment acting somewhat as a buffer to the lake and should be cultivated to promote a healthier environment and cleaner water.

\section{CONCLUSIONS}

This study found the presence of CECs in the sinkhole lake water, vegetation and sediments, an environment which allows rapid connections between surface water bodies and groundwater. We also determined that the hydraulic gradient of the source area can impact the levels of CECs present in lake water. The potential impact of CECs infiltration into karst aquifers such as the one in this area is of concern as the homeowners use wells as their source of drinking water. Consequently, one important outcome of this study is the need for wa- 
ter monitoring and the removal of OWTSs as the main method of waste water treatment. Contaminant infiltration must be determined before the water consumption and usage by humans. In addition, it would be useful to determine which CECs are most likely to infiltrate the aquifer. However, infiltration of CECs may differ in sinkhole lakes based on inputs and the topography surrounding the sinkhole lake environment. These karst aquifers, particularly the UFA, are important sources of drinking water. Although the karst system of Florida is our study area, the results are still applicable for many karst regions because of the high prevalence of OWTS worldwide.

The results of this study are useful for water resource managers for several reasons. First, lake vegetation is im- portant for the removal of harmful contaminants from the lake water showing its potential for reducing the potential pollution of the aquifer beneath the sinkhole lake. Consequently, these results show the importance of maintaining aquatic vegetation and a healthy riparian zone. Second, while we did not measure the presence of CECs in well water, there is potential for their presence, albeit at low concentrations. Consequently, year-round monitoring is important because the period of our study was conducted during the dry season. It is possible that the concentrations of the CECs will increase with the wet season's precipitation flushing the CECs into the lake and thereby increasing the potential for contamination of the below aquifers.

\section{REFERENCES}

Anumol, T., Merel, S., Clarke, B.O. \& S.A. Snyder, 2013: Ultra high performance liquid chromatography tandem mass spectrometry for rapid analysis of trace organic contaminants in water.- Chemistry Central Journal, 7, 1, 104. https://doi.org/10.1186/1752153X-7-104

Bloomfield, J.P., Williams, R.J., Gooddy, D.C., Cape, J.N. \& P. Guha, 2006: Impacts of climate change on the fate and behaviour of pesticides in surface and groundwater -- a UK perspective.- Science of the Total Environment, 369, 1-3, 163-177. https://doi. org/10.1016/j.scitotenv.2006.05.019

Brausch, J.M. \& G.M. Rand, 2011: A review of personal care products in the aquatic environment: Environmental concentrations and toxicity.- Chemosphere, 82, 11, 1518-1532. https://doi.org/10.1016/j.chemosphere.2010.11.018

Cardinale, T., 2000: Groundwater Contamination from Lake Grady Sinkhole \#2, A Water Management Division Report.- Environmental Protection Commission of Hillsborough County, Florida.

Carrara, C., Ptacek, C.J., Robertson, W.D., Blowes, W., Moncur, M.C. \& S. Backus, 2008: Fate of Pharmaceutical and Trace Organic Compounds in Three Septic System Plumes, Ontario, Canada.- Environmental Science \& Technology, 42, 8, 2805-2811. https://doi.org/10.1021/es070344q

Conn, K.E., Lowe, K.S., Drewes, J.E., Hoppe-Jones, C. \& M.B. Tucholke, 2010: Occurrence of pharmaceuticals and consumer product chemicals in raw wastewater and septic tank effluent from single-family homes.- Environmental Engineering Science, 27, 4, 347-356. https://doi.org/10.1089/ees.2009.0364
Del Rosario, K.L., Mitra, S., Humphrey, C.P. \& M.A. O'Driscoll, 2014: Detection of pharmaceuticals and other personal care products in groundwater beneath and adjacent to onsite wastewater treatment systems in a coastal plain shallow aquifer.- Science of the Total Environment, 487, 1, 216-223. https:// doi.org/10.1016/j.scitotenv.2014.03.135

Deng, C., Wang, S. \& F. Li, 2009: Research on soil multimedia environmental pollution around a $\mathrm{Pb}-\mathrm{Zn}$ mining and smelting plant in the karst area of Guangxi Zhuang Autonomous Region, Southwest China.- Chinese Journal of Geochemistry, 28, 2, 188-197. https://doi.org/10.1007/s11631-009-01885

Dodgen, L.K., Kelly, W.R., Panno, S.V., Taylor, S.J., Armstrong, D.L., Wiles, K.N., Zhang, Y. \& W. Zheng, 2017: Characterizing pharmaceutical, personal care product, and hormone contamination in a karst aquifer of southwestern Illinois, USA, using water quality and stream flow parameters.- Science of the Total Environment, 578, 281-289. https://doi. org/10.1016/j.scitotenv.2016.10.103

Dohrenwend, R.E., 1977: Evapotranspiration patterns in Florida.- Florida Scientist, 40, 2, 184-192.

Edwards, Q.A., Kulikov, S.M., Garner-O'Neale, L.D., Metcalfe, C.D. \& T. Sultana, 2017: Contaminants of emerging concern in surface waters in Barbados, West Indies.- Environmental monitoring and assessment, 189, 12, 636. https://doi.org/ 10.1007/ s10661-017-6341-4

Fairbairn, D.J., Karpuzcu, M.E., Arnold, W.A., Barber, B.L., Kaufenberg, E.F., Koskinen, W.C., Novak, P.J., Rice, P.J. \& D.L. Swackhamer, 2015: Sediment-water 
distribution of contaminants of emerging concern in a mixed use watershed.- Science of the Total Environment, 505, 896-904. https://doi.org/10.1016/j. scitotenv.2014.10.046

Florida Department of Environmental Protection, 2015: Aquifers.- [Online] Available from: fldep.dep.state. fl.us/swapp/Aquifer.asp\#SAS [Accessed 12th January 2020].

Godfrey, E., Woessner, W.W. \& M.J. Benotti, 2007: Pharmaceuticals in on-site sewage effluent and ground water, western Montana.- Groundwater, 45, 3, 263-271. https://doi.org/10.1111/j.17456584.2006.00288.x.

Google Maps, 2019: Study Area in Riverview Florida located at $27^{\circ} 50^{\prime} 09.5^{\prime \prime} \mathrm{N} 82^{\circ} 16^{\prime} 46.4^{\prime \prime W}$.- [Online] Available from: https://www.google. com/maps/@27.8351735,-82.2785955,626m/ data $=! 3 \mathrm{~m} 1 ! 1 \mathrm{e} 3$ [Accessed 5th January 2020].

Goswami, L., Vinoth Kumar, R., Borah, S.N., Arul Manikandan, N., Pakshirajan, K. \& G. Pugazhenthi, 2018: Membrane bioreactor and integrated membrane bioreactor systems for micropollutant removal from wastewater: A review.- Journal of Water Process Engineering, 26, 314-328. https://doi.org/10.1016/j. jwpe.2018.10.024

Gutiérrez, F., Parise, M., De Waele, J. \& H. Jourde, 2014: A review on natural and human-induced geohazards and impacts in karst.- Earth-Science Reviews, 138, 61-88. https://doi.org/10.1016/j.earscirev.2014.08.002

Haber, J.D. \& G. Mayfield, 2003: Sinkhole Formation at Lake Grady, Florida.- In: Florea, L.J. et al. (eds.) Karst studies in west central Florida: USF seminar in karst environments. Brooksville, Southwest Florida Water Management District, 53-64.

Katz, B.G. \& D.W. Griffin, 2008: Using chemical and microbiological indicators to track the impacts from the land application of treated municipal wastewater and other sources on groundwater quality in a karstic springs basin.- Environmental Geology, 55, 4, 801-821. https://doi.org/ 10.1007/s00254-007$1033-y$

Katz, B.G., Griffin, D.W., McMahon, P.B., Harden, H.S., Wade, E., Hicks, R.W. \& J.P. Chanton, 2010: Fate of effluent-borne contaminants beneath septic tank drainfields overlying a karst aquifer.- Journal of environmental quality, 39, 4, 1181-1195. https://doi. org $/ 10.2134 /$ jeq2009.0244

Kaufmann, G. \& W. Dreybrodt, 2007: Calcite dissolution kinetics in the system $\mathrm{CaCO} 3-\mathrm{H} 2 \mathrm{O}-\mathrm{CO} 2$ at high undersaturation.- Geochimica et Cosmochimica Acta, 71, 6, 1398-1410. https://doi.org/10.1016/j. gca.2006.10.024
Li, Q., Wang, P., Chen, L., Gao, H. \& L. Wu, 2016: Acute toxicity and histopathological effects of naproxen in zebrafish (Danio rerio) early life stages.- Environmental Science and Pollution Research, 23, 18, 18832-18841. https://doi.org/10.1007/s11356-0167092-4

Petrie, B., Smith, B.D., Youdan, J., Barden, R. \& B. Kasprzyk-Hordern, 2017: Multi-residue determination of micropollutants in Phragmites australis from constructed wetlands using microwave assisted extraction and ultra-high-performance liquid chromatography tandem mass spectrometry.Analytica Chimica Acta, 959, 91-101. https://doi. org/10.1016/j.aca.2016.12.042

Phillips, J.D., 1989: An evaluation of the factors determining the effectiveness of water quality buffer zones.- Journal of Hydrology, 107, 1, 133-145.

Prosser, R.S. \& P.K. Sibley, 2015: Human health risk assessment of pharmaceuticals and personal care products in plant tissue due to biosolids and manure amendments, and wastewater irrigation.- Environment international, 75, 223-233. https://doi. org/10.1016/j.envint.2014.11.020

Ricart, M., Guasch, H., Alberch, M., Barceló, D., Bonnineau, C., Geiszinger, A., Ferrer, J., Ricciardi, F., Romaní, A.M., Morin, S. \& L. Proia, 2010: Triclosan persistence through wastewater treatment plants and its potential toxic effects on river biofilms.- Aquatic Toxicology, 100, 4, 346-353. https:// doi.org/10.1016/j.aquatox.2010.08.010

Schnoor, J.L., Light, L.A., McCutcheon, S.C., Wolfe, N.L. \& L.H. Carreia, 1995: Phytoremediation of organic and nutrient contaminants.- Environmental science \& technology, 29, 7, 318A-323A. https://doi. org/10.1021/es00007a002

Seal, T., Woeber, N.A. \& J. Silvanima, 2016: Using tracers to infer potential extent of emerging contaminants in Florida's groundwater.- Florida Scientist, 279289.

Shrestha, S., Semkuyu, D.J. \& V.P. Pandey, 2016: Assessment of groundwater vulnerability and risk to pollution in Kathmandu Valley, Nepal.- Science of the Total Environment, 556, 23-35. https://doi. org/10.1016/j.scitotenv.2016.03.021

Singh, S.P., Azua, A., Chaudhary, A., Khan, S., Willett, K.L. \& P.R. Gardinali, 2010: Occurrence and distribution of steroids, hormones and selected pharmaceuticals in South Florida coastal environments.- Ecotoxicology, 19, 2, 338-350. https://doi. org/10.1007/s10646-009-0416-0

State of Florida, Department of Health, 2018: Chapter 64e-6, Florida Administrative Code Standards for Onsite Sewage Treatment and Disposal Systems. 
Subedi, B., Codru, N., Dziewulski, D.M., Wilson, L.R., Xue, J., Yun, S., Braun-Howland, E.,

Minihane, C. \& K. Kannan, 2015: A pilot study on the assessment of trace organic contaminants including pharmaceuticals and personal care products from on-site wastewater treatment systems along Skaneateles Lake in New York State, USA.- Water Research, 72, 28- 39. https://doi.org/10.1016/j.watres.2014.10.049

Svenningsen, H., Henriksen, T., Priemé, A. \& A.R. Johnsen, 2011: Triclosan affects the microbial community in simulated sewage-drain-field soil and slows down xenobiotic degradation.- Environmental Pollution, 159, 6, 1599-1605. https://doi.org/10.1016/j. envpol.2011.02.052

Tang-Liu, D.D., Williams, R.L. \& S. Riegelman, 1983: Disposition of caffeine and its metabolites in man.- Journal of Pharmacology and Experimental Therapeutics, 224, 1, 180-185.

Tihansky, A.B., 1999: Sinkholes, west-central Florida.Land subsidence in the United States: US geological survey circular, 1182, 121-140.
Weeks, J.A., Guiney, P.D. \& A.I. Nikiforov, 2012: Assessment of the environmental fate and ecotoxicity of $\mathrm{N}, \mathrm{N}$-diethyl-m-toluamide (DEET).- Integrated Environmental Assessment and Management, 8, 1, 120-134. https://doi.org/10.1002/ieam.1246

Wu, X., Ernst, F., Conkle, J.L. \& J. Gan, 2013: Comparative uptake and translocation of pharmaceutical and personal care products (PPCPs) by common vegetables.- Environment International, 60, 15-22. https:// doi.org/10.1016/j.envint.2013.07.015

Zhang, Y., Cao, W., Wang, W. \& Q. Dong, 2013: Distribution of groundwater arsenic and hydraulic gradient along the shallow groundwater flow-path in Hetao Plain, Northern China.- Journal of Geochemical Exploration, 135, 31-39. https://doi.org/10.1016/j. gexplo.2012.12.004

Zhang, S., Wang, Z. \& J. Chen, 2019: Physiologically based toxicokinetics (PBTK) models for pharmaceuticals and personal care products in wild common carp (Cyprinus carpio).- Chemosphere, 220, 793-801. https://doi.org/10.1016/j.chemosphere.2018.12.172 